\title{
Effect of Time of Planting on the Marketable Yield of Two Snap Bean Varieties at Isabela, Puerto Rico ${ }^{1}$
}

\author{
Gerardo Mangual Crespo ${ }^{2}$
}

\begin{abstract}
Snap bean experimental plantings established seasonally during 1972-73 at Isabela, P.R. demonstrated that the optimal planting season extends from December to March.

Variety Contender outyielded Wade in all plantings and showed a tendency to flower twice. This characteristic is not detrimental if the harvest is to be made in several pickings but could be unfavorable if the once-over harvest system is to be adopted.
\end{abstract}

\section{INTRODUCTION}

Despite the absence of snow or freezing temperatures, tropical regions are subject to seasonal changes which affect the yield of many crops, including snap beans (Phaseolus vulgaris).

High temperatures during the flowering stage may cause flower and small pod drops in snap bean, according to Davis (1), thus reducing the yield. Smith and Pryor (4) found that high temperatures during flowering consistently reduced pod set in two out of three field bean varieties in California. Zaumeyer (5) found that flowers and pods may drop during excessively hot or rainy weather. Harvest sometimes is delayed up to six weeks after flowering, while under normal climatic conditions it is completed two weeks after flowering. In delayed harvest, total yield increases but quality diminishes rapidly after seed development is visible. Lambeth (3) reported that temperatures over $26^{\circ} \mathrm{C}$ during the period 24 hours after anthesis reduced pod set in snap bean variety Tendergreen, thus reducing yield.

Yields obtained by Domenech and Mangual (2) for Wade and Contender in 1971 from February, March and June plantings were: 12.25, 20.22 and 8.50 tons/ha for Wade and 15.53, 24.27 and 9.77 tons/ha for Contender, respectively.

The mean annual rainfall at the Isabela Substation is $1651 \mathrm{~mm}$, May being the rainiest month with an average of $203 \mathrm{~mm}$ and February the driest with an average of $76 \mathrm{~mm}$.

This paper reports on trials conducted to determine the best planting

1 Manuscript submitted to Editorial Board September 30, 1974.

2 Research Assistant, Agricultural Experiment Station, Mayagüez Campus, University of Puerto Rico, Isabela, P.R. 
season for snap beans under the conditions prevailing at Isabela, Puerto Rico.

\section{MATERIALS AND METHODS}

Four plantings were made during 1972-73 (March, June, September, December) at the Agricultural Experiment Substation, Isabela, in a Coto clay, an Oxisol, which is the typical soil of the region.

A randomized block design with five replications of two commercial varieties (Wade and Contender) was used. Seed was sown by hand approxmately $8 \mathrm{~cm}$ apart in rows $90 \mathrm{~cm}$ apart and 12 meters long. Dacthal 75W was applied as a preemergent herbicide immediately after planting at the rate of $11.25 \mathrm{~kg}$ of the active ingredient/ha. Overhead irrigation was applied

TABLE 1.-Marketable yield in tons/ha of two snap bean varieties planted in four different months at the Isabela Substation, 1978-791

\begin{tabular}{lcrrrr}
\hline Variety & March & June & September & December & Mean \\
\hline Contender & $22.20^{2}$ & 13.67 & 11.20 & 24.45 & 17.87 \\
Wade & 14.92 & 7.65 & 7.52 & 20.10 & 12.55 \\
\hline Mean & 18.56 & 10.66 & 9.36 & 22.28 & 15.22 \\
Difference & 7.28 & 6.02 & 3.68 & 4.35 & \\
\hline
\end{tabular}

${ }^{1}$ Reported yield based on four pickings except in September, when three pickings were made.

${ }^{2}$ All differences in yield between varieties are significant at the 5 percent level.

twice during the first week and once weekly afterwards until flowering. Furrow irrigation was used as necessary. A weekly preventive spraying program was followed, mixing Diazinon AG 500 and Dithane M-45 at the rate of $1200 \mathrm{mls}$ and $2.25 \mathrm{~kg} / \mathrm{ha}$, respectively, to reduce damage by insects and diseases.

Each experiment was harvested at weekly intervals, picked four times except in September. Data from each picking was recorded for total, marketable and culled yield.

\section{RESULTS AND DISCUSSION}

Significant marketable yield differences at the 5 percent level occurred among varieties (table 1). Contender outyielded Wade in all plantings. This tendency was also noted by Domenech and Mangual (2) during the 1971 plantings.

As shown in table 1 December is the optimal planting month for both Wade and Contender, followed by March. Yields were lower in June and September. These findings agree with the general observations of the farmers in the area, who claim they obtain the best yields with field beans 
during the December, March and April plantings. Climatological data for the experimental planting period are presented in table 2.

Low yields obtained from the June and September plantings appear to resemble the findings of Smith and Pryor (4) and Zaumeyer (5), (table 1).

High marketable yields of Contender were due mainly to a second flowering which yielded at the rate of 8.52 tons/ha in the last picking in March, 75 days after planting.

The multiple flowering habit of Contender is not detrimental if the harvest is to be made in several pickings but, could be unfavorable under a once-over harvest system.

\section{RESUMEN}

Con el fin de observar el efecto que la época de siembra podría ejercer en el rendimiento de habichuelas tiernas de las variedades Wade y Contender, se hicieron cuatro

TABLE 2.-Growing period and corresponding climatic conditions for the four snap bean plantings at the Isabela Agricultural Experiment Substation from

September 1972 to August 1978

\begin{tabular}{lllccc}
\hline \multicolumn{1}{c}{ Planting date } & Harvest started & Harvest ended & $\begin{array}{c}\text { Mean } \\
\text { maximum } \\
\text { temper- } \\
\text { ature }\end{array}$ & $\begin{array}{c}\text { Mean } \\
\text { minimum } \\
\text { temper- } \\
\text { ature }\end{array}$ & Rainfall \\
\hline September 21/72 & November 5/72 & November 26/72 & 29 & 21 & 381 \\
December 21/72 & February 4/73 & March 6/73 & 28 & 19 & 127 \\
March 22/73 & May 10/73 & June 6/73 & 30 & 19 & 254 \\
June 21/73 & August 6/73 & August 27/73 & 31 & 21 & 406 \\
\hline
\end{tabular}

siembras en marzo, junio, septiembre y diciembre en la Subestación Experimental de Isabela, Puerto Rico.

La semilla se sembró a mano aproximadamente a $8 \mathrm{~cm}$. en hileras de 12 metros de largo y espaciadas a $90 \mathrm{~cm}$. entre sí.

Los resultados demostraron que el período entre diciembre y marzo es la mejor época para sembrar ambas variedades.

El rendimiento por hectárea de la variedad Contender fue más elevado y superó significativamente al de la Wade en todas las siembras.

En la variedad Contender se notó propensión a florecer dos veces en las siembras de diciembre y marzo.

\section{LITERATURE CITED}

1. Davis, J. F., The effect of some environmental factors on the set of pods and yield of white pea beans. J. Agr. Res. 70: 237-49, 1945.

2. Domenech, J. and Mangual, G., Snap bean variety trials and planting time, Agr. Exp. Sta. Univ. of P.R. Unpublished data.

3. Lambeth, V. N., Some factors influencing pod set and yield of the lima bean, Missouri Agr. Exp. Sta. Res. Bul. 466, 1950.

4. Smith, F. L. and Pryor, R. H., Effects of maximum temperature and age on flowering and seed production in 3 bean varieties, Hilgardia 33(12): 669, 1962.

5. Zaumeyer, W. J., Snap beans for marketing, canning and freezing, USDA Farmers Bul. No. 1915, page 2-9, 1954. 